\title{
A Novel Strategy for MALDI-TOF MS Analysis of Small Molecules
}

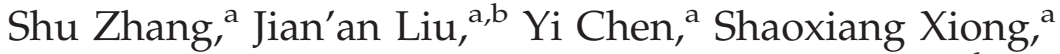 \\ Guanghui Wang, ${ }^{a}$ Jun Chen, ${ }^{a}$ and Guoqiang Yang ${ }^{a, b}$ \\ a Institute of Chemistry, Chinese Academy of Sciences, Beijing 100190, China \\ ${ }^{b}$ Beijing National Laboratory for Molecular Science, Beijing 100190, China
}

\begin{abstract}
Matrix-assisted laser desorption/ionization time-of-flight mass spectrometry (MALDI-TOF MS) does not work efficiently on small molecules (usually with molecular weight below $500 \mathrm{Da}$ ) because of the interference of matrix-related peaks in low $\mathrm{m} / \mathrm{z}$ region. The previous methods developed for this problem focused on reducing the peaks caused by the traditional matrices. Here, we report a novel strategy to analyze small molecules in a high and interference-free mass range by using metal-phthalocyanines (MPcs) as matrices which should be capable of forming matrix-analyte adducts. The mass of the target analyte was calculated by subtracting the mass of MPc from the mass of the MPc-analyte adduct. MPcs were also detectable and could serve as internal standards. Various MPcs with aromatic or aliphatic groups and different metal centers were then synthesized and explored. Aluminum-phthalocyanines (AlPcs), gallium-phthalocyanines (GaPcs), and indium-phthalocyanines (InPcs) were efficient matrices to form MPc-analyte adducts in either the positive or negative ion mode. The detection limits varied from 17 to $75 \mathrm{fmol}$, depending on analyte types. The mechanism of adducts formation was also proposed. Collectively, our strategy provides a novel and efficient way to analyze small molecules by MALDI-TOF MS. (J Am Soc Mass Spectrom 2010, 21, 154-160) (C) 2010 American Society for Mass Spectrometry
\end{abstract}

$\mathrm{M}$ atrix-assisted laser desorption/ionization timeof-flight mass spectrometry (MALDI-TOF MS) $[1,2]$ is limited for the detection of small molecules (usually with molar mass below $500 \mathrm{Da}$ ) because of the interference peaks caused by matrix. To solve this problem, several methods have been reported, of which the most attractive is the matrix-free laser desorption/ionization [3-13]. Siuzdak et al. [3] designed a porous silicon surface; the explorations were extended to not only the new types of silicon materials (e.g., silicon nanocavity [6] and silicon nanowires [7]), but also non-silicon substances such as porous aluminum [8] and zinc oxide nanoparticles [9]. Surfaceenhanced laser desorption/ionization (SELDI) introduced by Hutchens and Yip [10] is also a matrix-free method for biological samples analysis [11, 12]. This technique is combined with porous silicon surface through modifying the surface to make it capture analytes [13, 14].

Use of matrix additivies [15-18] is capable of reducing background peaks in low $\mathrm{m} / \mathrm{z}$ region as well. Guo et al. [15] added a surfactant of cetrimonium bromide to a conventional matrix of $\alpha$-cyano-4-hydroxycinnamic acid (CHCA) to suppress substantially the matrix-induced background.

Address reprint requests to Dr. Y. Chen and Dr. S. Xiong, Institute of Chemistry, Chinese Academy of Sciences, Beijing 100190, China. E-mail: chenyi@iccas.ac.cn and mscbj@iccas.ac.cn
Some researchers explored new matrices, such as carbon nanotubes [19], graphite [20, 21], ionic liquid [22, 23], and also some high-mass molecules. Ayorinde et al. [24] have reported the use of meso-tetrakis (pentafluorophenyl) porphyrin (F20TPP) as a matrix in MALDI-TOF MS analysis of some commercial nonylphenol ethoxylates and the fatty acids of saponified vegetable oil.

The strategy involved in these discussed methods lies in reducing the interference in the low mass region, which is difficult to completely realize. These methods also have other shortcomings, such as irreproducibility of silicon surface, significant reduction addition of $\mathrm{CTAB}$, and contamination of ion source from carbon nanotubes.

Herein, we developed a novel strategy, which is completely different from the approaches discussed above, to analyze small molecules by MALDI-TOF MS. The traditional stainless-steel plate was used, and no additives were used to suppress the matrix effect in this method. Small analytes were detected in the form of matrix-analyte adduct in a higher mass region by using metal-phthalocyanines (MPcs) as matrices, which resulted in the elimination of the interference peaks in low mass region derived from traditional matrices. Unlike porphyrin matrix [24], the MPcs matrices not only absorb laser energy but also can form MPc-analyte adducts.

Several key factors affecting the formation of MPcanalyte adducts, such as matrix/analyte molar ratio, central metal ions, and substituent groups of MPcs, as 
well as samples' $\mathrm{pK}_{\mathrm{a}}$, are discussed in detail. This new method has been successfully applied to the analyses of various types of small molecules, including peptides, fatty acids, and phenol.

\section{Experimental}

\section{Materials}

Gibberellic acid $\left(\mathrm{GA}_{3}\right)$ was purchased from Acros (Fair Lawn, New Jersey, USA). 2,5-Dihydroxy benzoic acid, quercetin, and luteolin were from Sigma (St. Louis, MO, USA). Salicylic acid, $\alpha$-cyano-4-hydroxycinnmaic acid, palmitic acid, vitamin C, 3-nitrophthalonitrile, 1,2,3,4tetrahydro-9-acridanone, and other chemicals were from Aldrich (Milwaukee, WI, USA).

\section{MPcs Synthesis}

The MPcs (Scheme 1) used in this paper were synthesized from the respective chlorides following previously reported methods with some modifications [2527]. The synthetic process was laid out with $\mathrm{M}(\mathrm{aPc}) \mathrm{s}$ as

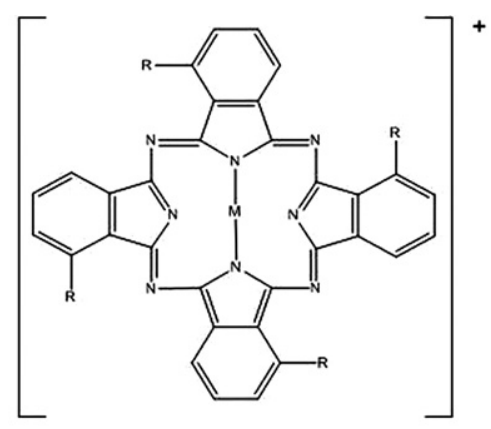

\begin{tabular}{|c|c|c|c|c|}
\hline Compound & M & $\mathrm{R}$ & Abbreviation & Exact Mass \\
\hline 1 & $\mathrm{Al}^{3+}$ & & {$[\mathrm{Al}(\mathrm{aPc})]^{+}$} & 827.36084 \\
\hline 2 & $\mathrm{Ga}^{3+}$ & & {$[\mathrm{Ga}(\mathrm{aPc})]^{+}$} & 869.30488 \\
\hline 3 & $\operatorname{In}^{3+}$ & $(\mathrm{aPc}$ & {$[\mathrm{In}(\mathrm{aPc})]^{+}$} & 915.28318 \\
\hline 4 & $\mathrm{Al}^{3+}$ & & {$[\mathrm{Al}(\mathrm{pPc})]^{+}$} & 1131.48604 \\
\hline 5 & $\mathrm{Ga}^{3+}$ & & {$[\mathrm{Ga}(\mathrm{pPc})]^{+}$} & 1173.43009 \\
\hline 6 & $\operatorname{In}^{3+}$ & $(\mathrm{pPc})$ & {$[\operatorname{In}(\mathrm{pPc})]^{+}$} & 1219.40838 \\
\hline 7 & $\mathrm{Mg}^{2+}$ & & {$[\mathrm{Mg}(\mathrm{hPc})]$} & 968.21935 \\
\hline 8 & $\mathrm{Zn}^{2+}$ & $(\mathrm{hPc})$ & {$[\mathrm{Zn}(\mathrm{hPc})]$} & 1008.16346 \\
\hline 9 & $\mathrm{SnO}^{2+}$ & & {$[\mathrm{SnO}(\mathrm{Pc})]$} & 648.04690 \\
\hline 10 & $\mathrm{SnF}_{2}{ }^{2+}$ & $\begin{array}{l}\text { Non } \\
\text { (Pc) }\end{array}$ & {$\left[\mathrm{SnF}_{2}(\mathrm{Pc})\right]$} & 670.04880 \\
\hline 11 & $\mathrm{TiO}^{2+}$ & & {$[\mathrm{TiO}(\mathrm{Pc})]$} & 576.09265 \\
\hline
\end{tabular}

Scheme 1. The structures of the metal-phthalocyanine compounds. an example. Briefly, 3-nitrophthalonitrile (1.73 g or 10 $\mathrm{mmol}$ ) was treated with 2-methyl-1-propanol in the presence of anhydrous $\mathrm{K}_{2} \mathrm{CO}_{3}$ to form $\alpha$-(2-methylpropyloxy) phthalonitrile. After cyclization of the substituted phthalonitrile using lithium in $n$-butanol, a metal-free phthalocyanine $(\mathrm{Pc})$ was obtained and further reacted with $\mathrm{AlCl}_{3}$, $\mathrm{GaCl}_{3}$ or $\mathrm{InCl}_{3}$ in $\mathrm{N}, \mathrm{N}$-dimethylformamide to form $\mathrm{M}(\mathrm{aPc}) \mathrm{s}$. The resulting $\mathrm{M}(\mathrm{aPc}) \mathrm{s}$ (chlorides) were characterized by MALDI-TOF MS, UV-Vis and NMR (data not shown).

\section{UV-Vis Absorption Measurement}

MPcs were separately dissolved in tetrahydrofuran (THF) at a final concentration of $1 \mu \mathrm{M}$. With pure THF as a reference, their UV absorption spectra were recorded on a double beam UV-Vis spectrophotometer, model TU-1900 from Purkinje General Instrument Co. Ltd. (Beijing, China) by scanning from 200 to $500 \mathrm{~nm}$ at room temperature.

\section{Mass Spectrometry}

All mass spectrometry experiments were performed on an Autoflex III MALDI-TOF mass spectrometer (Bruker Daltonics, Bremen, Germany) equipped with a 355-nm nitrogen laser. Before the experiment, the instrument was calibrated using an external standard calibration mixture composed of angiotensin I, angiotensin II, Substance P, bombesin, adrenocorticotropic hormone clip 1-17, and clip 18-39, and somatostatin 28 from the Bruker Daltonics.

Samples and MPcs were dissolved in THF separately and mixed. The mixture was spotted on the SCOUT MTP 384 MALDI target plate. Mass spectra were acquired in reflectron mode with an acceleration voltage of $19 \mathrm{kV}$ and laser frequency of $10 \mathrm{~Hz}$. The laser power was set at $40 \%$ to $90 \%$ of the maximum. Usually 30-200 laser shots were accumulated for each spectrum.

\section{Results and Discussion}

The Application of MPcs as Matrices Enhanced Efficiently the Detection of Small Molecules by $M A L D I-M S$

MPcs are an important type of industrial materials widely used in printing, dye industry and especially the CD-manufacturing processes. With a conjugated $\pi$ system, they have a Soret absorption band between 290 and $450 \mathrm{~nm}$ attributed to the $4 \mathrm{a}_{2 \mathrm{u}} \rightarrow 6 \mathrm{e}_{\mathrm{g}} \pi-\pi$ orbit transition. Our experiments showed that they absorb laser energy at $355 \mathrm{~nm}$ from the MALDI-TOF mass spectrometer and can be desorpted/ionized without the use of traditional matrix.

In our experiments, MPcs were not only used as matrix to absorb laser energy, but also brought small analytes to a higher mass region through conjugation reaction. Figure 1a shows the mass spectra of citric acid in positive mode when using CHCA (upper line) and 

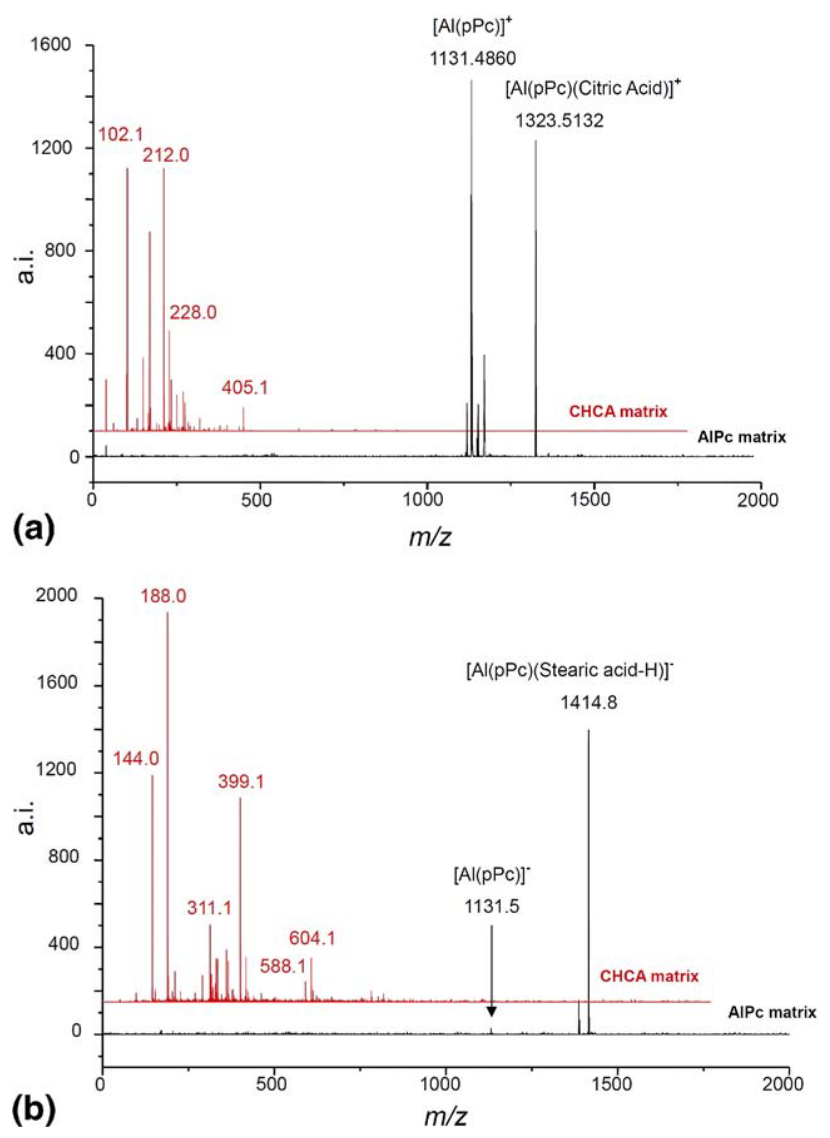

Figure 1. Comparison of MALDI mass spectra using AlPc matrix and CHCA matrix in analysis of (a) citric acid in positive mode and (b) stearic acid in negative mode.

$\mathrm{Al}(\mathrm{pPc})$ (lower line) as a matrix, respectively. Citric acid was hardly detected using CHCA because of the highabundance background signals from CHCA in low mass range. When $\mathrm{Al}(\mathrm{pPc})$ was used, the peak of matrix-analyte adduct, in the form of $[\mathrm{Al}(\mathrm{pPc})(\mathrm{citric}$ acid) $]^{+}$, was detected with high intensity and good resolution in higher mass region. In addition, we observed the $[\mathrm{Al}(\mathrm{pPc})]^{+}$ion. More data are shown in Table 1.

In the negative-ion mode (Figure 1b), stearic acid was used to compare the MALDI-mass spectra acquired, while $\mathrm{CHCA}$ (upper line) or $\mathrm{Al}(\mathrm{pPc}$ ) (lower line) was used as a matrix. The spectrum was noisy in the low mass range when CHCA was employed as the matrix. CHCA-related peaks, such as the ions of 188.0 $\left([\mathrm{M}-\mathrm{H}]^{-}\right), 399.1\left([2 \mathrm{M}-2 \mathrm{H}+\mathrm{Na}]^{-}\right)$, were very intense. On the other hand, a very clean spectrum was obtained when $\mathrm{Al}(\mathrm{pPc})$ matrix was used. The stearic acid was detected in the form of $[\mathrm{Al}(\mathrm{pPc})(\text { stearic acid }-\mathrm{H})]^{-}$with high intensity. In addition, the peak of $[\mathrm{Al}(\mathrm{pPc})]^{-}$was also obvious, albeit with relatively weak signal.

This method was applied to the detection of gibberellic acid $\left(\mathrm{GA}_{3}\right)$, an important phytohormone. Due to its low molecular weight, $\mathrm{GA}_{3}$ is difficult to be analyzed by MALDI-TOF MS. Until now, no one has reported the analysis of $\mathrm{GA}_{3}$ using conjugation reaction by MALDI-MS technique. Excitingly, our new method can clearly detect $\mathrm{GA}_{3}$ with good signal in the negative-ion mode. Other small molecules, such as amino acids, small peptides, fatty acids, flavones, and so on, were successfully detected (data shown in Table 2). We conclude that MPcs can be widely employed as matrices to analyze various types of small molecules by MALDI-MS.

\section{Analyte Mass Calculation}

The molar mass of small molecules can be easily calculated from MPc-analyte adduct. In the positive mode, the mass of the analyte is equal to the adduct mass subtracted by the mass of the MPc. For example, in Figure 1a (lower line) the mass of citric acid is 1323.5132 $1131.4860=192.0272$, which agrees very well with the theoretical value of 192.0270 . When the $[\mathrm{MPc}]^{+}$signal was intense enough, it offered the opportunity as a reference ion for the internal calibration. Table 1 lists the accurate masses and mass measurement errors of a group of analytes after calibration with $[\mathrm{MPc}]^{+}$ions. In the negative-ion mode (Figure $1 \mathrm{~b}$ lower line), the complex exists in the form of $[\mathrm{Al}(\mathrm{pPc})$ (stearic acid $-\mathrm{H})]^{-}$. Thus, the mass of stearic acid is $1414.8-1131.5+1.0=$ 284.3, which is again consistent with the theoretical value.

\section{Matrix/Analyte Molar Ratio Affects the Formation of MPc-Analyte Adducts}

In traditional MALDI-TOF MS analysis, the normal molar ratio of matrix to sample varies from 1500:1 to

Table 1. Results of small molecules analyzed by MALDI-TOF using $\mathrm{Al}(\mathrm{pPc})$ as matrix in positive-ion mode with analyte/matrix molar ratio of 5:1

\begin{tabular}{lcccrr}
\hline \multicolumn{1}{c}{ Analyte or $\mathrm{HA}$} & Molecular formula & $\mathrm{M}_{[\mathrm{Al}(\mathrm{pPc}) \bullet \mathrm{HA}]}{ }^{\mathrm{a}}$ & $\mathrm{M}_{\mathrm{HA}}{ }^{\mathrm{b}}$ & $\mathrm{M}^{\prime}{ }_{\mathrm{HA}}{ }^{\mathrm{c}}$ & $\mathrm{Error}_{\text {ppm }}$ \\
\hline \hline$\alpha$-Cyano-4-hydroxycinnmaic acid & $\mathrm{C}_{10} \mathrm{H}_{7} \mathrm{NO}_{3}$ & 1320.5295 & 189.0435 & 189.0426 & 5 \\
2, 5-Dihydroxy benzoic acid & $\mathrm{C}_{7} \mathrm{H}_{6} \mathrm{O}_{4}$ & 1285.5131 & 154.0271 & 154.0266 & 3 \\
Salicylic acid & $\mathrm{C}_{7} \mathrm{H}_{6} \mathrm{O}_{3}$ & 1269.5170 & 138.0310 & 138.0317 & -5 \\
Citric acid & $\mathrm{C}_{6} \mathrm{H}_{8} \mathrm{O}_{7}$ & 1323.5132 & 192.0272 & 192.0270 & 1 \\
Gibberellic acid & $\mathrm{C}_{19} \mathrm{H}_{22} \mathrm{O}_{6}$ & 1477.6291 & 346.1431 & 346.1416 & 4 \\
1,2,3,4-Tetrahydro-9-acridanone & $\mathrm{C}_{13} \mathrm{H}_{13} \mathrm{NO}$ & 1330.5847 & 199.0987 & 199.0997 & -5 \\
\hline
\end{tabular}

${ }^{\mathrm{a}} \mathrm{M}_{[\mathrm{Al}(\mathrm{pPc}) \bullet \mathrm{HA}]}=$ mass of $[\mathrm{Al}(\mathrm{pPc}) \bullet \mathrm{HA}]^{+}$.

${ }^{\mathrm{b}} \mathrm{M}_{\mathrm{HA}}=\mathrm{M}_{[\mathrm{Al}(\mathrm{pPc}) \bullet \mathrm{HA}]}-\mathrm{M}_{[\mathrm{Al}(\mathrm{pPC})]}=\mathrm{M}_{[\mathrm{Al}(\mathrm{pPc}) \bullet \mathrm{HA}]}-1131.4860$.

${ }^{\mathrm{c}} \mathrm{M}_{\mathrm{HA}}^{\prime}=$ theoretical mass of $\mathrm{HA}$. 
Table 2. Results of small molecules analyzed by MALDI-TOF MS using $\mathrm{Al}(\mathrm{pPc})$ as matrix in negative-ion mode with analyte/matrix molar ratio of 5:1

\begin{tabular}{|c|c|c|c|c|}
\hline Analyte or HA & Molecular formula & $\mathrm{M}_{[\mathrm{Al}(\mathrm{pPc}) \bullet \mathrm{A}]^{a}}$ & $\mathrm{M}_{\mathrm{HA}}^{\mathrm{b}}$ & $\mathrm{M}_{\mathrm{HA}}^{\prime}{ }^{\mathrm{c}}$ \\
\hline$\alpha$-Cyano-4-hydroxycinnmaic acid & $\mathrm{C}_{10} \mathrm{H}_{7} \mathrm{NO}_{3}$ & 1319.5 & 189.0 & 189.0 \\
\hline 2,5-Dihydroxy benzoic acid & $\mathrm{C}_{7} \mathrm{H}_{6} \mathrm{O}$ & 1284.5 & 154.0 & 154.0 \\
\hline Salicylic acid & $\mathrm{C}_{7} \mathrm{H}_{6} \mathrm{O}_{3}$ & 1268.5 & 138.0 & 138.0 \\
\hline Citric acid & $\mathrm{C}_{6} \mathrm{H}_{8} \mathrm{O}_{7}$ & 1322.5 & 192.0 & 192.0 \\
\hline Vitamin C & $\mathrm{C}_{6} \mathrm{H}_{8} \mathrm{O}_{6}$ & 1306.5 & 176.0 & 176.0 \\
\hline Vitamin pp & $\mathrm{C}_{6} \mathrm{H}_{5} \mathrm{NO}_{2}$ & 1253.5 & 123.0 & 123.0 \\
\hline Gibberellic acid & $\mathrm{C}_{19} \mathrm{H}_{22} \mathrm{O}_{6}$ & 1476.6 & 346.1 & 346.1 \\
\hline Cholic acid & $\mathrm{C}_{24} \mathrm{H}_{40} \mathrm{O}_{5}$ & 1538.8 & 408.3 & 408.3 \\
\hline Phe & $\mathrm{C}_{9} \mathrm{H}_{11} \mathrm{NO}_{2}$ & 1295.6 & 165.1 & 165.1 \\
\hline Lys & $\mathrm{C}_{6} \mathrm{H}_{14} \mathrm{~N}_{2} \mathrm{O}_{2}$ & 1276.6 & 146.1 & 146.1 \\
\hline Cys & $\mathrm{C}_{3} \mathrm{H}_{7} \mathrm{NO}_{2} \mathrm{~S}$ & 1251.5 & 121.0 & 121.0 \\
\hline Phe-Phe & $\mathrm{C}_{18} \mathrm{H}_{20} \mathrm{~N}_{2} \mathrm{O}_{3}$ & 1442.6 & 312.1 & 312.1 \\
\hline Asp-Phe & $\mathrm{C}_{13} \mathrm{H}_{16} \mathrm{~N}_{2} \mathrm{O}_{5}$ & 1410.6 & 280.1 & 280.1 \\
\hline Luteolin & $\mathrm{C}_{15} \mathrm{H}_{10} \mathrm{O}_{6}$ & 1416.5 & 286.0 & 286.0 \\
\hline Quercetin & $\mathrm{C}_{15} \mathrm{H}_{10} \mathrm{O}_{7}$ & 1432.5 & 302.0 & 302.0 \\
\hline Palmitic acid & $\mathrm{C}_{16} \mathrm{H}_{32} \mathrm{O}_{2}$ & 1386.7 & 256.2 & 256.2 \\
\hline Stearic acid & $\mathrm{C}_{18} \mathrm{H}_{36} \mathrm{O}_{2}$ & 1414.8 & 284.3 & 284.3 \\
\hline 4,4'-(3,6-Diethynyl-9H-fluorene-9,9-diyl)diphenol & $\mathrm{C}_{29} \mathrm{H}_{18} \mathrm{O}_{2}$ & 1528.6 & 398.1 & 398.1 \\
\hline 4-tert-Butylphenol & $\mathrm{C}_{10} \mathrm{H}_{14} \mathrm{O}$ & 1280.6 & 150.1 & 150.1 \\
\hline 2-Methyl-1,3,4,10-trtrahydro-9(2H)-acridinone & $\mathrm{C}_{14} \mathrm{H}_{15} \mathrm{NO}$ & 1343.6 & 213.1 & 213.1 \\
\hline 1,2,3,4-Tetrahydro-9-acridanone & $\mathrm{C}_{13} \mathrm{H}_{13} \mathrm{NO}$ & 1329.6 & 199.1 & 199.1 \\
\hline Norharmane & $\mathrm{C}_{11} \mathrm{H}_{8} \mathrm{~N}_{2}$ & 1298.6 & 168.1 & 168.1 \\
\hline
\end{tabular}

${ }^{\mathrm{a}} \mathrm{M}_{[\mathrm{Al}(\mathrm{pPc}) \bullet \mathrm{A}]}=$ mass of $[\mathrm{Al}(\mathrm{pPc}) \bullet A]^{-}$.

${ }^{b} M_{H A}=M_{[A l(p P c) \bullet A]}-M_{[A l(p P c)]}+M_{H}=M_{[A l(p P c) \bullet A]}-1131.5+1.0=M_{[A l(p P c) \bullet A]}-1130.5$.

${ }^{\mathrm{c}} \mathrm{M}_{\mathrm{HA}}^{\prime}=$ theoretical mass of $\mathrm{HA}$.

3000:1 depending on the species and molecular weight of samples [28]. To obtain a clean spectrum with good signal intensity, MPc/sample molar ratio used in our experiment was in the range of 10:1 to $1: 10$. When the ratio was higher than 10:1, the peak intensity of MPc was very strong, which makes it difficult to detect the MPc-analyte complex in the positive mode. When lower than 1:10, large amount of analyte crystals hindered the effective absorption of laser energy and desorption/ionization of the complex.

\section{Different Metal Centers and Substituent Groups Affect Substantially the Formation of the MPc-Analyte Adducts}

Central metal ions of MPcs had crucial influences on the formation of matrix-analyte adducts. In this study, only the trivalent metal ions from the Group IIIla gave rise to desirable adduct signals. A metal ion with high valence like $\mathrm{Sn}^{4+}$ or $\mathrm{Ti}^{4+}$ (Scheme 1, Compounds 9-11) can hardly yield target ions but many signals of by-products, mainly due to their oxidative properties. The metal ion with a lower valence, such as $\mathrm{Zn}^{2+}$ or $\mathrm{Mg}^{2+}$ (Scheme 1, Compounds 7 and 8 ), also resulted in no target signals, probably because MPc with a divalent metal ion cannot offer extra charges to form stable analyte-matrix adducts.

Figure 2 shows that the signal intensity of analyte$\mathrm{Al}(\mathrm{pPc})$ adducts is much stronger than those of other two metal ions in Group IIIa, with an order of $\mathrm{Al}^{3+} \gg$ $\mathrm{Ga}^{3+}>\mathrm{In}^{3+}$. This is consistent with the ion sizes and their abilities to form a complex. The valence electron structures of central metal elements are $3 s^{2} 3 p^{1}$, $3 \mathrm{~d}^{10} 4 \mathrm{~s}^{2} 4 \mathrm{p}^{1}$, and $4 \mathrm{~d}^{10} 5 \mathrm{~s}^{2} 5 \mathrm{p}^{1}$ for $\mathrm{Al}, \mathrm{Ga}$, and In, respectively. After orbital hybridization, the central ions can coordinate with four equivalent nitrogen atoms of a phthalocyanine molecule to give square planar complexes. However, if analytes act as ligands, the square planar complexes will be converted to octahedron

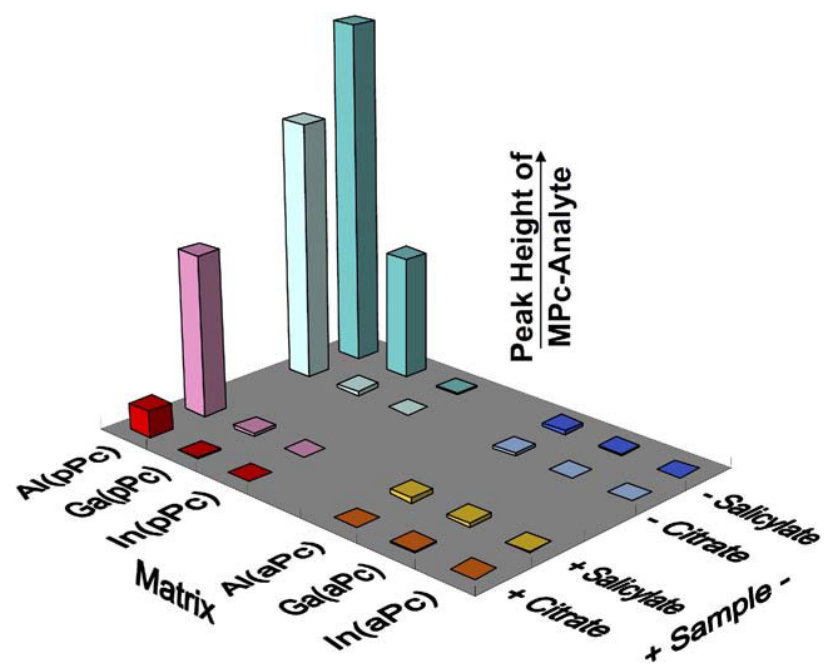

Figure 2. Comparison of peak heights of MPc-analyte adduct by using $\mathrm{M}(\mathrm{pPc})$ and $\mathrm{M}(\mathrm{aPc})$ as matrices; salicylic, and citric acid were employed as testing samples. The peak height was normalized by $h / N P$, where $h$ is the measured peak height, $N$ is the accumulation times and $P$ is the laser power setting. 


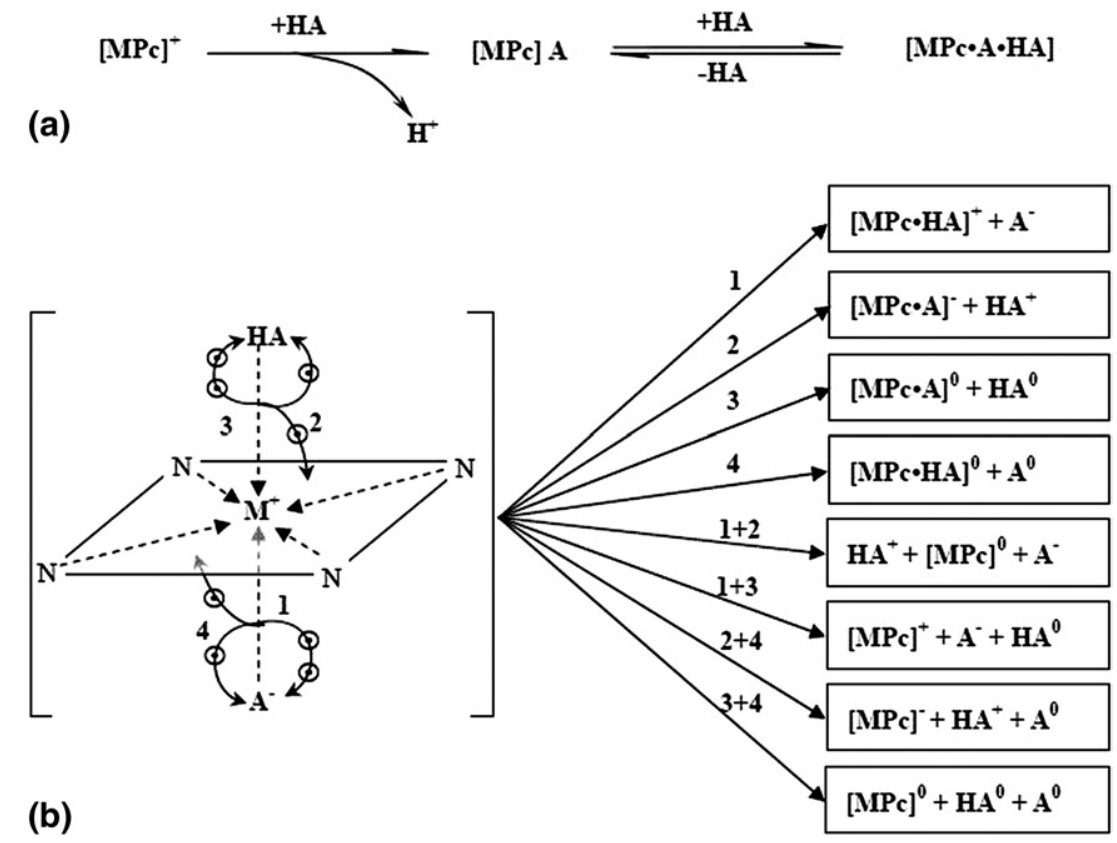

Scheme 2. (a) Proposed reactions occurring between MPc matrix and analyte HA; (b) The most probable ionization routes for the octahedron complex [MPc.A.HA].

structures. As a consequence, both square and octahedron complexes may coexist through the reactions (shown in Scheme 2a). Scheme 2a illustrates the main reactions possibly occurring between MPc and analyte, in which HA represents the analyte. Scheme $2 b$ shows the octahedron complex structure and the most probable ionization routes for [MPc.A.HA].

Different substituting groups on the Pc ring, which was originally introduced to improve its solubility [29, 30], also affect the formation of MPc-analyte adducts. In this study, MPc with phenyl and alkyl groups, $\mathrm{M}(\mathrm{pPc})$ and $\mathrm{M}(\mathrm{aPc})$, were used to test the influences. Figure 2 shows that peak intensity of $\mathrm{M}(\mathrm{pPc})$-analytes is much higher than that of $\mathrm{M}(\mathrm{aPc})$-analytes. Furthermore, the signals of salicylic acid complexes are higher than those of citric acid. These results suggest there might be a $\pi-\pi$ interaction between analyte and MPc, which can stabilize the matrix-analyte adducts.

\section{The Influence of Sample $p K_{a}$ on the Formation of MPc-Analyte Adducts}

Besides the MPc matrix, the sample $\mathrm{pK}_{\mathrm{a}}$ also affects the interaction between analytes and MPcs. Six small molecules with different $\mathrm{pK}_{\mathrm{a}}$ values [31-35] were mixed at an equimolar ratio and analyzed. The resulted mass spectrum (Figure 3) showed only five target peaks. The expected complex peak of indole was not found because it did not conjugate with MPc. The matrixanalyte peak intensity increased with the increase of the samples' acidity or with the decrease of their $\mathrm{pK}_{\mathrm{a}}$ values. It implies that electrostatic interaction plays an important role in the formation of the analytematrix adducts.

\section{The Detection Limit of the MALDI-MS While} MPcs Were Used as Matrices

The detection limit was evaluated with $\mathrm{GA}_{3}$ as the representative analyte. It was $75 \mathrm{fmol}$ when $\mathrm{GA}_{3}$ was analyzed by MALDI-TOF MS in negative mode using $\mathrm{Al}(\mathrm{pPc})$ as a matrix at the sample/matrix molar ratio of 5:1. When CHCA was used as the testing analyte, the detection limit was lowered to $17 \mathrm{fmol}$. The main reason lies in that CHCA $\left(\mathrm{pK}_{\mathrm{a}}=1.2\right)$ [17] is more acidic than $\mathrm{GA}_{3}\left(\mathrm{pK}_{\mathrm{a}}=3.8\right)$ [36], thus it can form much stronger complex than $\mathrm{GA}_{3}$ at even a much lower concentration. Moreover, CHCA bears a phenyl ring, able to form a more stable complex with $\mathrm{Al}(\mathrm{pPc})$ through $\pi-\pi$ interaction. Therefore, small molecules with aromatic group (s) and lower $\mathrm{pK}_{\mathrm{a}}$ will commonly produce better detection limit when using $\mathrm{Al}(\mathrm{pPc})$ or $\mathrm{Al}(\mathrm{aPc})$ as a matrix.

\section{Conclusions}

In summary, we report a novel strategy to detect small molecules ( $<500 \mathrm{Da})$ by MALDI-TOF MS using MPcs as matrices. This new type of matrix is multifunctional; it not only absorbs laser energy but also forms MPcanalyte adduct, which can be easily detected during MALDI-MS analysis. Moreover, MPcs are also able to serve as the internal standards and thus have the potential for elemental composition determination based on accurate mass measurement. The molar ratio of matrix/ sample, the metal center and substituent group of MPcs, the $\mathrm{pK}_{\mathrm{a}}$ value of samples affect substantially the analyte signal intensity. With this new strategy, a variety of small molecules, including amino acids, peptides, fatty acids, etc., were successfully detected. Because of its 

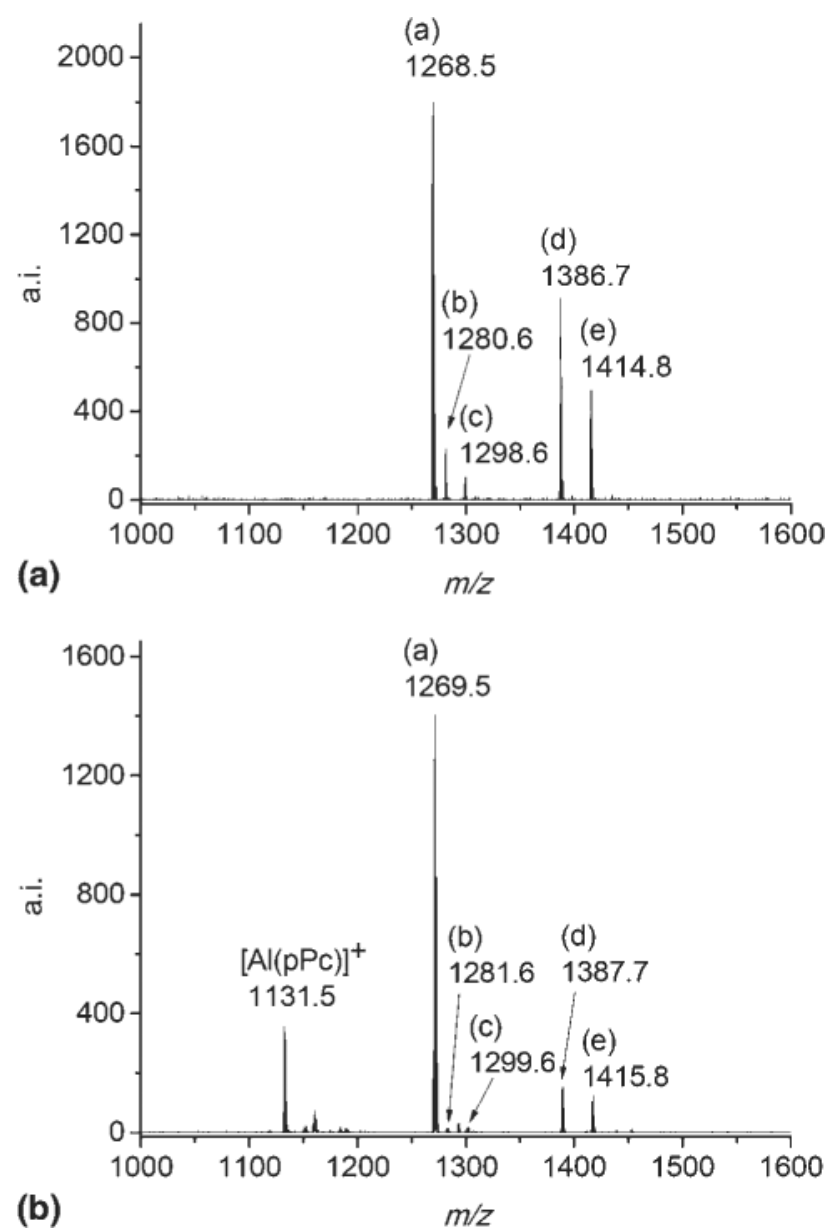

Figure 3. Mass spectra of mixed analytes measured in (a) negative and (b) positive ion modes with $\mathrm{Al}(\mathrm{pPc})$ as matrix. Peak identities: (a) Salicylic acid $\left(\mathrm{pK}_{\mathrm{a}}=2.97\right)$; (b) 4-tert-Butylphenol $\left(\mathrm{pK}_{\mathrm{a}}=10.39\right)$; (c) Norharmane $\left(\mathrm{pK}_{\mathrm{a}}=14.9\right)$; (d) Palmitic acid $\left(\mathrm{pK}_{\mathrm{a}}=9.7\right)$; (e) Stearic acid $\left(\mathrm{pK}_{\mathrm{a}}=10.15\right)$; (f) Indole $\left(\mathrm{pK}_{\mathrm{a}}=16.2\right.$, no peak detected).

high specificity and sensitivity, this method is being applied to the detection of gibberellins (GAs) in plant crude extract. We believe that soon this strategy will become an efficient tool for the facile and direct analysis of small molecules in complex biological matrices.

\section{Acknowledgments}

The authors acknowledge financial support for this work by NSFC (no. 90717120 and 20628507), MOST (no. 2007CB714504), Sino-German Center for Research Promotion (GZ364), and CAS (KJCX2-YW-H11).

\section{References}

1. Tanaka, K.; Waki, H.; Ido, Y.; Akita, S.; Yoshida, Y.; Yoshida, T. Protein and Polymer Analyses up to $\mathrm{m} / \mathrm{z} 100,000$ by Laser Ionization Time-ofFlight Mass Spectrometry. Rapid Commun. Mass Spectrom. 1988, 2, 151-153.

2. Karas, M.; Hillenkamp, F. Laser Desorption Ionization of Proteins with Molecular Masses Exceeding 10,000 Daltons. Anal. Chem. 1988, 60, 2299-2301.

3. Wei, J.; Buriak, J. M.; Siuzdak, G. Desorption-Ionization Mass Spectrometry on Porous Silicon. Nature 1999, 399, 243-246.

4. Thomas, J. J.; Shen, Z.; Crowell, J. E.; Finn, M. G.; Siuzdak, G. Desorption/Ionization on Silicon (DIOS): A Diverse Mass Spectrometry
Platform for Protein Characterization. Proc. Natl. Acad. Sci. U.S.A. 2001, 98, 4932-4937.

5. Bhattacharya, S. H.; Raiford, T. J.; Murray, K. K. Infrared Laser Desorption/Ionization on Silicon. Anal. Chem. 2002, 74, 2228-2231.

6. Finkel, N. H.; Prevo, B. G.; Velev, O. D.; He, L. Ordered Silicon Nanocavity Arrays in Surface-Assisted Desorption/Ionization Mass Spectrometry. Anal. Chem. 2005, 77, 1088-1095.

7. Go, E. P.; Apon, J. V.; Luo, G.; Saghatelian, A.; Daniels, R. H.; Sahi, V. Dubrow, R.; Cravatt, B. F.; Vertes, A.; Siuzdak, G. Desorption/Ionization on Silicon Nanowires. Anal. Chem. 2005, 77, 1641-1646.

8. Nayak, R.; Knapp, D. R. Effects of Thin-Film Structural Parameters on Laser Desorption/Ionization from Porous Alumina. Anal. Chem. 2007, 79, 4950-4956.

9. Watanabe, T.; Kawasaki, H.; Yonezawa, T.; Arakawa, R. SurfaceAssisted Laser Desorption/Ionization Mass Spectrometry (SALDI-MS) of Low Molecular Weight Organic Compounds and Synthetic Polymers Using Zinc Oxide (ZnO) Nanoparticles. J. Mass Spectrom. 2008, 43, 1063-1071.

10. Hutchens, T. W.; Yip, T. T. New Desorption Strategies for the Mass Spectrometric Analysis of Macromolecules. Rapid Commun. Mass Spectrom. 1993, 7, 576-580.

11. Tang, N.; Tornatore, P.; Weinberger, S. R. Current Developments in SELDI Affinity Technology. Mass Spectrom. Rev. 2004, 23, 34-44.

12. Issaq, H. J.; Conrads, T. P.; Prieto, D. A.; Tirumalai, R.; Veenstra, T. D. SELDI-TOF MS for Diagnostic Proteomics. Anal. Chem. 2003, 75, 148A155A.

13. Trauger, S. A.; Go, E. P.; Shen, Z. X.; Apon, J. V.; Compton, B. J.; Bouvier E. S. P.; Finn, M. G.; Siuzdak, G. High Sensitivity and Analyte Capture with Desorption/Ionization Mass Spectrometry on Silylated Porous Silicon. Anal. Chem. 2004, 76, 4484-4489.

14. Meng, J. C.; Siuzdak, G.; Finn, M. G. Affinity Mass Spectrometry from a Tailored Porous Silicon Surface. Chem. Commun. 2004, 18, 2108-2109.

15. Guo, Z.; Zhang, Q.; Zou, H.; Guo, B.; Ni, J. A Method for the Analysis of Low-Mass Molecules by MALDI-TOF Mass Spectrometry. Anal. Chem. 2002, 74, 1637-1641.

16. McCombie, G.; Knochenmuss, R. Small-Molecule MALDI Using the Matrix Suppression Effect to Reduce or Eliminate Matrix Background Interferences. Anal. Chem. 2004, 76, 4990-4997.

17. Guo, Z.; He, L. A Binary Matrix for Background Suppression in MALDI-MS of Small Molecules. Anal. Bioanal. Chem. 2007, 387, 19391944.

18. Trimpin, S.; Clemmer, D. E.; McEwen, C. N. Charge-Remote Fragmentation of Lithiated Fatty Acids on a TOF-TOF Instrument Using MatrixIonization. J. Am. Soc. Mass Spectrom. 2007, 18, 1967-1972.

19. Xu, S.; Li, Y. Zou, H.; Qiu, J.; Guo, Z: Guo, B. Carbon Nanotubes as Assisted Matrix for Laser Desorption/Ionization Time-of-Flight Mass Spectrometry. Anal. Chem. 2003, 75, 6191-6195.

20. Black, C.; Poile, C.; Langley, J.; Herniman, J. The Use of Pencil Lead as a Matrix and Calibrant for Matrix-Assisted Laser Desorption/Ionization. Rapid Commun. Mass Spectrom. 2006, 20, 1053-1060.

21. Langley, G. J.; Herniman, J. M.; Townell, M. S. 2B or not 2B, That is the Question: Further Investigations into the Use of Pencil as a Matrix for Matrix-Assisted Laser Desorption/Ionization. Rapid Commun. Mass Spectrom. 2007, 21, 180-190.

22. Mank, M.; Stahl, B.; Boehm, G. 2,5-Dihydroxybenzoic Acid Butylamine and Other Ionic Liquid Matrixes for Enhanced MALDI-MS Analysis of Biomolecules. Anal. Chem. 2004, 76, 2938-2950.

23. Tholey, A.; Heinzle, E. Ionic (Liquid) Matrices for Matrix-Assisted Laser Desorption/Ionization Mass Spectrometry-Applications and Perspectives. Anal. Bioanal. Chem. 2006, 386, 24-37.

24. Ayorinde, F. O.; Hambright, P.; Porter, T. N.; Keith, Q. L., Jr. Use of Meso-Tetrakis(Pentafluorophenyl)Porphyrin as a Matrix for Low Molecular Weight Alkylphenol Ethoxylates in Laser Desorption/Ionization Time-of-Flight Mass Spectrometry. Rapid Commun. Mass Spectrom. 1999, 13, 2474-2479.

25. Wang, S.; Gan, Q.; Shen, S.; Xu, H.; Yang, G. Optical Limiting Properties of a Soluble Chloro-indium Phthalocyanine. Acta Chim. Sinica 2004, 22, 2209-2212.

26. Gan, Q.; Li, S.; Morlet-Savary, F.; Wang, S.; Shen, S.; Xu, H.; Yang, G. Photophysical Properties and Optical Limiting Property of a Soluble Chloroaluminum-Phthalocyanine. Opt. Express 2005, 13, $5424-$ 5433 .

27. Wang, S.; Gan, Q.; Zhang, Y.; Li, S.; Xu, H.; Yang, G. Optical-Limiting and Photophysical Properties of Two Soluble Chloroindium Phthalocyanines with $\alpha$ - and $\beta$-Alkoxyl Substituents. Chem. Phys. Chem. 2006, 7, 935-941.

28. Goldschmidt, R. J.; Wetzel, S. J.; Blair, W. R.; Guttman, C. M. PostSource Decay in the Analysis of Polystyrene by Matrix-Assisted Laser Desorption/Ionization Time-of-Flight Mass Spectrometry. J. Am. Soc. Mass Spectrom. 2000, 11, 1095-1106.

29. Durmus, M.; Nyokong, T. Synthesis, Photophysical and Photochemica Properties of Tetra- and Octa-Substituted Gallium and Indium Phthalocyanines. Polyhedron. 2007, 26, 3323-3335.

30. Xiao, K.; Liu, Y.; Huang, X.; Xu, Y.; Yu, G.; Zhu, D. Field-Effect Transistors Based on Langmuir-Blodgett Films of Phthalocyanine De- 
rivatives as Semiconductor Layers. J. Phys. Chem. B 2003, 107, 92269230.

31. The $\mathrm{pK}_{\mathrm{a}}$ Value of Salicylic Acid Was Found from the Website: http:// goldbamboo.com/topic-t8324-a1-6Salicylates.html.

32. Kanicky, J. R.; Shah, D. O. Effect of Degree, Type, and Position of Unsaturation on the $\mathrm{pK}(\mathrm{a})$ of Long-chain Fatty Acids. J. Colloid Interface Sci. 2002, 256, 201-207.

33. The $\mathrm{pK}_{\mathrm{a}}$ Value of 4-tert-Butylphenol Was Found from the Website: http:// www.inchem.org/documents/sids/sids/98544.pdf.
34. Biondic, M. C.; Erra-Balsells, R. Photochemical Behavior of â-Carbolines. 4. Acid-Base Equilibria in the Ground and Excited States in Organic Media. J. Chem. Soc. Perkin Trans. 2 1997, 2, 1323-1327.

35. The $\mathrm{pK}_{\mathrm{a}}$ Value of Indole Was Picked up from: http://en.wikipedia.org/ wiki/Indole.

36. Tian, X.; Knapp, A. D.; Gibson, L. R.; Struthers, R.; Moore, K. J. Brummer, E. C.; Bailey, T. B. Response of Eastern Gamagrass Seed to Gibberellic Acid Buffered Below Its $\mathrm{pK}_{\mathrm{a}}$. Crop. Sci. 2003, 43, 927933. 